Carolin Schröder, Heike Walk

\title{
Co-operatives and climate protection: housing co-operatives in Germany
}

Book Part, Postprint Version

This version is available at http://dx.doi.org/10.14279/depositonce-6653

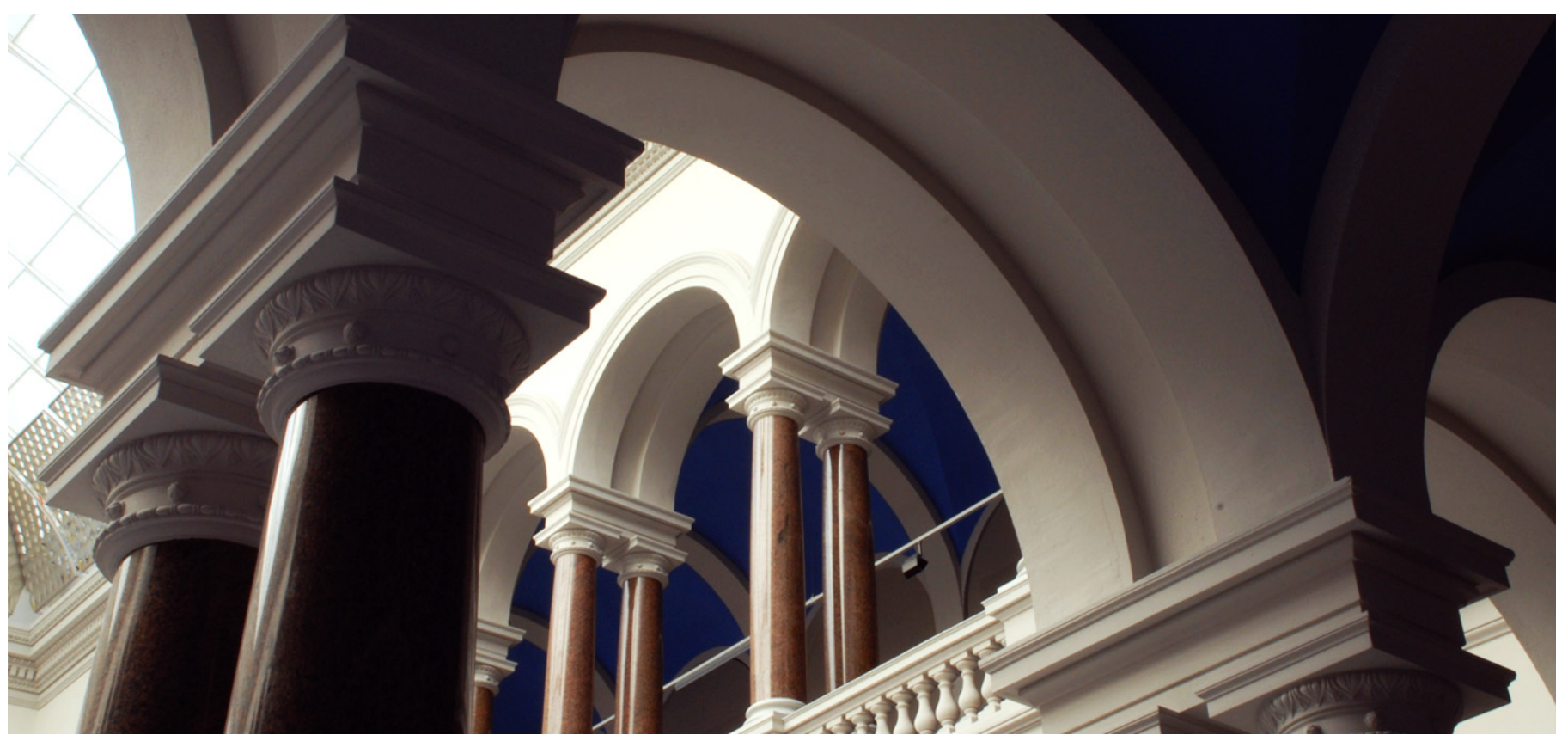

\section{Suggested Citation}

Schröder, Carolin; Walk, Heike: Co-operatives and climate protection: housing co-operatives in Germany. - In: Webster et al. (eds.): Mainstreaming co-operation: an alternative for the twenty-first century? - Manchester:Manchester University Press, 2016. - ISBN: 978-0-7190-9959-5 (print). - pp. 201-220. - DOI: 10.7228/manchester/9780719099595.003.0012. (Postprint, page numbers differ.) 


\section{Co-operatives and climate protection: housing co-operatives in} Germany

\section{Carolin Schröder and Heike Walk}

\section{Introduction}

After the Fifth Assessment Report of the Intergovernmental Panel on Climate Change (IPCC) it became clear that global climate change was progressing much more rapidly than assumed a few years before. ${ }^{1}$ The need for action is therefore all the more urgent - and we need to turn our attention above all to the collective activities and social dimensions of climate change and climate protection. In Germany, through the adopted Integrated Energy and Climate Programme of the Federal German government and the legal framework for action on climate change in 2007, municipal climate protection experienced a further increase. There are hardly any communities or towns that have not committed themselves to this issue. However, we are still observing a strong east-west and north-south divide, with the degree of commitment being much higher in the south and in the west. While in the 1990s municipal climate policies concentrated exclusively on climate protection ${ }^{2}$, in 2008 the Federal Cabinet adopted the German Strategy for Adaptation to Climate Change. This created a framework for adapting to the impact of climate change in Germany.

This chapter argues that great potential for climate protection activities can be found precisely in co-operatives and that co-operatives will become increasingly important for local sustainable solutions because of their capacity for participation and solidarity. The chapter starts with a short description of the need for climate protection at the local level, followed by an outline on co-operatives as collective actors for climate protection - with emphasis on their democratic and solidary capacity.

Further, an introduction to the German co-operative sector is supplemented by research results on three different housing co-operatives and their climate-related activities, which provide insight into their participatory and solidary capacity, since these attributes can promote climate protection and sustainability projects and efforts. Finally, the concluding section addresses crucial aspects that facilitate participatory and solidary structures.

\section{The need for climate protection at the local level}

Climate change is a major challenge affecting most global, national and local economies, societies and natural resources in various ways: extreme weather events (storms, floodings, heat waves or droughts), rising sea levels, changes in precipitation rates (rainfall/snow, 
droughts etc.) and temperature averages. These events will affect people directly (in particular, the poorest), as they make livelihoods and living conditions more vulnerable. While climate change has quite diverse effects in different parts of the world and different impacts on population groups (women and men, rich and poor, old and young, urban and rural population etc.), areas of close geographical proximity may face very different challenges and thus require very different, location-specific approaches.

As a result, global climate change and its consequences have led to wide-ranging reevaluation processes in both political and business circles: for a considerable time, climate protection activities on the global and national levels focused on technical solutions and legally binding agreements, but these have achieved rather poor results so far. ${ }^{3}$ In consequence, municipalities developed and implemented regional and local climate protection activities from the mid-1990s onwards which combined technical and social aspects of climate protection and aimed at including a variety of participation of civil society actors, businesses and institutions. This approach is based on the insights

- that climate-protective technologies need to be adapted to their uses and users in order to be successful;

- that climate policies can rather be influenced at the local and regional level; and

- that the co-operation and participation of large parts of the society are crucial. ${ }^{4}$

Although action is still voluntary, at time of writing in 2014 many municipalities in Western Europe and in Germany have already presented more or less comprehensive climate protection concepts which are aimed at transforming municipal production and consumption patterns in order to move towards more sustainable societies. Obviously, the scope of action for local climate protection is limited to measures within municipal legal and socio-political capacities. This ranges from adapting technical solutions to local conditions, to supporting more vulnerable population groups, and to promoting changes of individual climate-relevant behaviour and investment decisions.

\section{Co-operatives as collective actors for climate protection}

Co-operatives are of specific interest when it comes to collective action for climate protection. They represent a well-established and institutionalised form of civil organisation with a diverse presence worldwide. The specific qualities of co-operatives - in particular their interconnected economic and social sustainability in times of rapid economic, social and technical changes ${ }^{5}$ - prompted us to consider their potential ecological sustainability too. In the context of climate change, this raised the question to what extent co-operatives or, to be more precise, the co-operative movement - could contribute to climate protection at the local and the global levels. 
While they address various social, cultural, ecological and economic everyday needs cooperatives 'are based on the values of self-help, selfresponsibility, democracy, equality, equity and solidarity' while their 'members believe in the ethical values of honesty, openness, social responsibility and caring for others' ${ }^{6}$ Their specific logic of collective action is characterised by an appreciation of local democracy and solidarity, ${ }^{7}$ as co-operatives are inextricably linked to the sustainable functioning of local communities and markets. ${ }^{8}$ Patera even describes co-operatives as an 'emancipatory social system' ${ }^{9}$

Regarding co-operatives' capacities for climate protection, such an emancipatory social system can be considered as a solid base for designing and implementing local policies and strategies in, for example, housing, consumption, mobility and health that are related to the socio-economic characteristics (income, gender, age and health) of their members. Cooperatives networking with other groups and institutions may even have greater effects on local climate protection than individual activities. Quite obviously, this cannot be generalised as co-operatives vary in size and engagement, and in resources available. But at their best, they may develop and implement individual and collective strategies of dealing with, adapting or rather escaping the effects of climate change in the short, medium and long run. ${ }^{10}$ In the following section, we focus on the co-operative capacities of democracy and solidarity and their relevance, arguing that the principles of self-help and shared responsibility can trigger considerable bursts of motivation, specifically with regard to climate protection.

\section{Democratic capacities}

The participatory rights of co-operators differ fundamentally from the influential power of shareholders in other business forms: co-operatives as interest groups formed by individuals take their decisions democratically, transparently and based on equal rights ${ }^{11}$, with value creation remaining member oriented and collectively available. Indeed, the participatory rights are appreciated by most members and considered a great advantage. ${ }^{12}$ But the level and number of participatory activities vary from attending an annual assembly to delegates and work groups entitled to prepare or take decisions on specific topics. ${ }^{13}$ On the one hand, we find co-operatives where only a minority of members exercise their democratic rights via attending the annual assembly. Lack of time is the most prominent reason given that prevents members from participating.

Thus, in consequence, the formation of will and the making of decisions, the two core elements of participation, are frequently concentrated in the board of directors, ${ }^{14}$ not to mention the implementation of decisions. On the other hand, we find a considerable number of new, small co-operatives where members are actively participating in shaping objectives and services for a sustainable and climate-friendly future. The latter conceive involvement in collective structures as a practical opportunity to become informed and involved, to meet people, to support each other within a self-chosen community, to break 
down global problems into collective and local ones, to counteract feelings of powerlessness, and to collectively implement local solutions to specific problems. ${ }^{15}$

\section{Co-operatives as organisations based on the notion of solidarity}

The literature on co-operatives describes solidarity as one of their central values. Many authors argue that the idea of solidarity between people with similar interests stabilises the group, ${ }^{16}$ and contributes to population groups' coping with several societal deficits. ${ }^{17}$ However, only a few studies explicitly examine the notion and goals of solidarity in the cooperative context. This may be due to the general difficulty of capturing this concept. In the 1990s a couple of studies were conducted which identified trust as a key prerequisite for cooperative solidarity: Gherardi and Masiero describe solidarity in co-operatives as a relational pattern, as a form of collective action or network activity that builds on trust and can therefore also be understood as a competitive factor that makes co-operatives stand out from the private economy. ${ }^{18}$ The recent trend to establish new, small co-operatives may be a consequence of this.

One challenge in the context of sustainable development would be to relate solidarity to climate protection. While there might be a diffuse consensus that global effects of climate change can only be dealt with via international solidarity between people and nations, it is worthwhile looking at potential contributions of co-operatives at the local level.

Solidarity-based climate protection activities could be promoted by co-operatives via their members' and staff's daily routines, guidelines and rules as well as via political lobbying. In addition, solidarity-based solutions could be developed which provide access to more sustainable lifestyles for people with less money. Or, vice versa, it could be the case that collective climate protection measures might promote cooperative solidarity. ${ }^{19}$

\section{The current situation of German co-operatives}

In a similar way to other countries, the first co-operative-like structures in Germany evolved within the agrarian and food sector. But unlike in England and France, where early socialists such as Robert Owen and Charles Fourier were instrumental in the development of the cooperative sector, the co-operative movement in Germany in the early twentieth century grew apart from the worker's movement - except for the housing and consumer cooperative sectors. ${ }^{20}$ Consequently, the most important spokespeople in Germany were neither peasants nor workers, but members of the middle class. Two particularly important spokesmen spread their Christian conservative and liberal ideas: Friedrich Wilhelm Raiffeisen and Hermann Schulze-Delitzsch. Raiffeisen, the founder of agricultural co-operation, was a young mayor in the slum areas of the Eifel. He acted within a framework of Christian conservative care. 
Schulze-Delitzsch, in turn, was a leftist politician and co-founder of the German Progressive Party. ${ }^{21}$ Along with the political ideas of these two leading German figures, the socialist and social reformist approach that characterised the co-operatives of the early twentieth century largely disappeared. Instead, economic benefits have gained more importance in large parts of today's German market-based co-operative model than aspects of solidarity.

Between 1950 and 1970, the number of registered co-operatives declined by almost a third (from more than 26,000 down to about 18,500 ), and in the three subsequent decades by another half (with only 9,500 registered co-operatives by the end of 1999 , and a mere 7,500 by 2006$)^{22}$ (Table 12.1). This can be explained by concentration in the financial co-operative sector and demutualisation in other sectors. Despite declining absolute figures, cooperatives still have more members than any other type of organisation, with some 20.5 million out of 80 million inhabitants Almost every German farmer is still a member of at least one co-operative, while more than 90 per cent of all bakers and butchers, an average of 60 per cent of craftsmen and an average 75 per cent of retailers are still organised in cooperatives. However, an ongoing concentration among credit and savings co-operatives can be observed. Nonetheless, there is a considerable number, especially of housing and producer co-operatives, to be found both in east and west Germany that date back well into the nineteenth century. The number of new co-operatives remains small, with just sixty newly registered co-operatives in 2003 in Germany (seventy-four in 2006), compared to more than 500,000 new registered businesses. ${ }^{23}$

Table 12.1: Number of co-operatives in Germany, 1980-2011

\begin{tabular}{|c|c|c|c|c|c|}
\hline & 1980 & 1990 & 2000 & 2010 & 2011 \\
\hline Co-operative banks & 4,267 & 3,055 & 1,813 & 1,156 & 1,139 \\
\hline Credit co-operatives & 4,246 & 3,037 & 1,794 & 1,138 & 1,121 \\
\hline Co-operative central banks & 10 & 4 & 4 & 2 & 2 \\
\hline Special affiliated co-operatives & 11 & 14 & 15 & 16 & 16 \\
\hline Rural co-operatives & 5,228 & 3,725 & 3,815 & 2,480 & 2,413 \\
\hline Primary co-operatives $a, b$ & 5,168 & 3,672 & 3,780 & 2,474 & 2,407 \\
\hline Head offices ${ }^{c}$ & 60 & 53 & 35 & 6 & 6 \\
\hline Industrial co-operatives ${ }^{a}$ & 875 & 787 & 1,422 & 2,018 & 2,338 \\
\hline Primary co-operatives & 856 & 772 & 1,410 & 2,009 & 2,329 \\
\hline Head offices & 19 & 15 & 12 & 9 & 9 \\
\hline
\end{tabular}




\begin{tabular}{|c|c|c|c|c|c|}
\hline Consumer's co-operatives & 94 & 30 & 53 & 33 & 31 \\
\hline Primary co-operatives & 55 & 28 & 51 & 32 & 30 \\
\hline Head offices & 39 & 2 & 2 & 1 & 1 \\
\hline Housing co-operatives & 1,217 & 1,172 & 1,991 & 1,931 & 1,921 \\
\hline Primary co-operatives & 1,217 & 1,172 & 1,991 & 1,931 & 1,921 \\
\hline Head offices & - & - & - & - & - \\
\hline Total & 11,681 & 8,769 & 9,094 & 7,618 & 7,842 \\
\hline \multicolumn{6}{|c|}{$\begin{array}{l}\text { a Water, electricity and refrigerated glasshouse co-operatives, listed as rural co-operatives } \\
\text { until } 2008 \text {, have been listed as industrial co-operatives since } 2009 \text {. The bioenergy, forestry } \\
\text { and timber co-operatives that were in part listed as industrial co-operatives until } 2008 \text { have } \\
\text { been listed as rural co-operatives since } 2009 .\end{array}$} \\
\hline \multicolumn{6}{|c|}{$\begin{array}{l}\text { b Excluding credit co-operatives with transactions in commodities. Including agricultural co- } \\
\text { operatives. }\end{array}$} \\
\hline
\end{tabular}

Note: Up to 1990, data includes only federal states in West Germany, using DM.

Source: DZ Research, 'Die deutschen Genossenschaften 2012. Entwicklungen - Meinungen Zahlen' (Wiesbaden: Deutscher Genossenschafts-Verlag eG, 2012), p. 40, www.corporateportal.dzbank.de/presse_detail.php?id=1342.

\section{Three current trends}

The number of co-operatives is growing in certain sectors of the German economy, but declining in others. On the one hand, there have been constant merging and consolidation processes, especially in the credit sector, which have reduced the number of co-operatives from initially 27,000 to 7,619 in $2011 .{ }^{24}$ On the other hand, there are growing numbers of new co-operatives, especially in the housing, energy and social sectors. There are three reasons for this.

Firstly, in a time of economic and social crisis the co-operative model is proving attractive in Germany. The consequences of decade-long privatisations and a growing mistrust in the established forms of (capitalist) economy have led to widespread discussions on the role of civil society in societal transformation processes. Examples of such discourses are the 
solidarity economy or 'post-growth society', which emphasises fundamentally different ideas of quality of life, access to resources, and civil society, economy and politics. ${ }^{25}$ The recent cooperative boom in Germany, especially in the energy and housing sectors, may be interpreted as a first reaction to this. To what extent the 2006 amendments to the German Co-operative Act $^{26}$ have contributed or will contribute to this is disputed among experts, and will surely differ from sector to sector. One significant amendment to the Act was that the corporate purpose of theco-operative can now include to social and cultural concerns, in addition to promoting the economic benefit of its members. Another change made the audit requirements easier for smaller organisations. ${ }^{27}$

A second impulse that boosted the growth of co-operatives at approximately the same time was triggered by a larger trend towards economically and socially sustainable organisations, alongside a general transformation of the energy system. An important reason for this rapid growth in this area - apart from the economic crisis - is that a law on renewable energies was introduced in $\mathbf{2 0 0 0}$ that made it much easier for small organisations to produce renewables. ${ }^{28}$ In consequence, and along with associations and private partnerships (Gesellschaft burgerlichen Rechts), it was primarily the co-operatives that conceived different business models in this sector, for instance by taking over electricity grids, and creating systems of community self-sufficiency and bioenergy villages. Between 2007 and 2014 , the total number of registered energy co-operatives in Germany grew to $973,{ }^{29}$ investing around 800 million euros into local or regional solar plants, wind farms and bioenergy plants by the time of writing. ${ }^{30}$

Thirdly, the United Nations (UN) International Year of co-operatives in 2012 and the UN decade of co-operatives (2011-20) have significantly added to the publicity of co-operatives worldwide. The boom reflects both an increasing number of scientific articles and media reports as well as in the above outlined growth developments in various sectors (Table 12.2). But interestingly, most data available on cooperatives refers to their economic and legal aspects. German social sciences and interdisciplinary studies, in contrast, have largely neglected co-operatives. In consequence, there are hardly any qualitative studies concerned with co-operatives or their activities, specifically the solidarity-oriented and participative structures of this form of organisation. Recent publications by Zimmer and by Munkner and Ringle, analysing co-operatives as actors of civic society, are exceptions. ${ }^{31}$

\section{Three housing co-operatives}

One of the many types of co-operatives aimed at actively supporting solidarity and sustainable structures is the housing co-operative. With 3 million members (out of 20 million co-op members altogether) and 2.2 million units to take care of, these co-operatives provide 10 per cent of Germany's total housing stock. As most of this housing was built either between 1880 and 1930 or between 1950 and 1970, the need for renovation is significant. In combination with comparatively high standards for energy efficiency and rising energy costs, 
this has the effect that housing co-operatives implement more measures to increase energy efficiency than any other public housing organisation, not to mention private households. ${ }^{32}$ There is a general interest among housing co-op members in investing money in their flats, because this has a dual function - members are both owners and users of the flats, creating a 'harmony of interests'. ${ }^{33}$ This increased interest in additional functions, which often include also participatory and solidary aspects, goes along with the observation that German housing co-operatives are most active when it comes to environment and climate protection. ${ }^{34}$ Below, we will present case studies of three German housing co-operatives and provide findings from our research regarding their specific participatory and solidary capacities.

Table 12.2: Co-operative members in Germany, by sector, 1980-2011

\begin{tabular}{|l|l|l|l|l|l|}
\hline Members (in thousands) & $\mathbf{1 3 , 2 7 5}$ & $\mathbf{1 5 , 2 0 7}$ & $\mathbf{2 0 , 0 7 4}$ & $\mathbf{2 0 , 7 4 4}$ & $\mathbf{2 1 , 1 5 5}$ \\
\hline Credit co-operatives $^{\prime}$ & 9,105 & 11,421 & 15,039 & 16,689 & 17,002 \\
\hline Rural co-operatives $^{\text {a, b }}$ & 1,555 & 1,205 & 922 & 563 & 550 \\
\hline Industrial co-operatives $^{\text {a }}$ & 337 & $\mathbf{2 5 7}$ & 255 & 315 & 407 \\
\hline Consumer's co-operatives $^{\prime}$ & 665 & 600 & 825 & 355 & 350 \\
\hline Housing co-operatives & 1,613 & 1,724 & 3,033 & 2,822 & 2,846 \\
\hline
\end{tabular}

${ }^{\text {a }}$ Water, electricity and refrigerated glasshouse co-operatives, listed as rural co-operatives until 2008, have been listed as industrial co-operatives since 2009. The bioenergy, forestry and timber co-operatives that were in part listed as industrial co-operatives until 2008 have been listed as rural co-operatives since 2009.

${ }^{b}$ Excluding credit co-operatives with transactions in commodities. Including agricultural cooperatives.

Note: Up to 1990, data includes only federal states in West Germany, using DM.

Source: DZ Research, 'Die deutschen Genossenschaften 2012. Entwicklungen - Meinungen Zahlen' (Wiesbaden: Deutscher Genossenschafts-Verlag eG, 2012), p. 40, www.corporateportal.dzbank.de/presse_detail.php?id=1342.

\section{Spar- und Bauverein Hannover eG}

The housing co-operative Spar- und Bauverein Hannover, was established in 1885. It offers more than 8,000 apartments all over the northern German town of Hanover, as well as several financial services to its 23,000 members, of which senior citizens constitute the majority. Since the mid-2000s, many buildings from the 1890s and 1950s have been renovated with energy-efficient insulation and new heating systems. In addition, the cooperative was also one of the first in Germany to build new co-operative housing, in the mid- 
2000s, starting a small wave of co-operative building in Germany. From the 1960s until the mid-2000s, German housing co-operatives either reduced their housing stock or took over existing buildings. The co-operative has introduced a specific recycling system to their members, and conducts a yearly monitoring of its climate protection activities. Plans for the future include the installation of photovoltaic systems on rooftops, individual water meters and triple-glazed windows, and the introduction of incentives for using public transportation and the co-operative's transport services.

\section{Participatory capacities}

The annual assembly is organised as an elected delegates meeting. As in many co-operatives, attendance rates are very low; approximately fifty people attend. This may be because this assembly's function is merely to approve the annual report and the activities of the board. Nonetheless, and in order to integrate a variety of members' needs, the management board set up a range of services such as neighbourhood meetings, tenant group holidays and daily assistance services for senior citizens. After the board of directors decided to establish new meeting spaces in three Hanover neighbourhoods, all members were invited in 2012 to collectively develop ideas for using those spaces. Again, around fifty people participated. Climate protection has become a crucial issue for the board of directors, for reasons of social responsibility as well as economic efficiency. To underline this, the co-operative is a member of the municipal climate alliance, sent a team of young members to the municipal solar mobile race in 2011 and offers consultation and workshops on practical energy efficiency (such as how to properly use the new heating systems) to their members. In 2013, two workshops (called world cafes) on 'climate protection and our co-op' took place, organised by the co-operative and our research team. Roughly one hundred members attended out of curiosity, as they admitted that they are interested in the topic but feel that they do not have enough economic and professional knowledge to discuss or vote on major investments for climate protection that do not relate to their daily experiences. Nevertheless, many new ideas for climate-related measures were suggested. Of course, some voiced scepticism about benefits of more participation in the co-operative's decisions.

\section{Solidary capacities}

Members describe solidarity as collective action that creates shared values and, in consequence, allows for joint investment, for example in renovating flats or neighbourhood meeting spaces. According to their views, solidarity should be expressed by mutual respect, and by using personal, barrier-free forms of communication. Interestingly, members express their trust in the executive board and the co-operative structure as such by agreeing to decisions and by not showing up at the annual meeting - instead of legitimising the executive board or introducing topics they are interested in.

The aspect of solidarity within the co-operative can be seen, for example, in the realising of equal rises in rent for old and new buildings and in a special interest in joint events that deal 
with future issues. For example, in 2012 a world cafe on communication, climate change and neighbourhood was carried out with the members. The number of participants was encouragingly high and the feedback from the participants on improving the living environment was very positive. Proposals have been developed, for example, on urban gardening, vegetable crates and energy conservation.

\section{Weiberwirtschaft eG}

The women's co-operative WeiberWirtschaft eG in central Berlin was established in 1992 to support women in green businesses. After renovating a former industrial site, they provide approximately 7,100 square metres of office space for some seventy businesses of different sizes, including a children's daycare facility, conference rooms, restaurants, a start-up service for women in green businesses, a meeting space for networking activities, and thirteen flats. The majority of the members are based in Berlin but others live in a variety of locations all over Germany and Europe.

The ecofriendly renovation of the site, financially supported by publicfunds from the Berlin state, concentrated on reducing energy consumption and harmful emissions. Due to their ecologically responsible overall concept, the co-operative won several national and European awards for their ecological concept (e.g. Naturschutzbund Germany 2004) and innovation (Prize of the Regions, Council of Europe, 2008). Up to the present day, international delegations come to visit this 'biggest start-up for women in green businesses in Europe'. In addition, bike parking, unsealed yards, green roofs and facades were realised, and nesting boxes and bee stocks were added in 2014 .

\section{Participatory capacities}

This co-operative is characterised by a heterogeneous member structure, as the interests of women renting the flats are somewhat different from those renting business spaces, those running the co-operative, and those living in Berlin, other parts of Germany or in Europe. In consequence, it is difficult for some women to attend the annual assembly, and personal communication between the residents and the business owners is more frequent than between other members.

Beyond annual meetings with comparatively low attendance rates, several work groups have existed over the years. Career counselling, networking and raising political awareness for women in green businesses constitute one major aim of the co-operative. It also has also become a European and global role model as many international visitors come to learn about environmentally friendly renovation and women-run green businesses. To its members, it also offers consultation on green investments, on recycling and on waste disposal. In practice, the decisions of the executive and the supervisory board are usually ratified by the members. 


\section{Solidary capacities}

Supporting women in green businesses and collectively solving individual problems of women in business are the shared objectives of the members. Unlike with many other cooperatives, knowledge exchange on solidarity and its practical implementation are a regular topic at meetings and in the newsletter. As one member of the managing board stated, this is 'part of the overall business strategy'. In consequence, a significant rent reduction for office and business spaces during the start-up phase was implemented. Some women even feel that this co-operative is less profit-oriented than others, as the members are economically independent from the co-operative.

Solidarity among members is shown by their investing collectively in printers, internet provision, counselling services and recycling systems. Similar to the Spar-and Bauverein Hannover, members argue that solidarity is also apparent in personal forms of communication, in mutual support in daily matters such as swapping flats according to changing needs, in sharing rent for collectively used office spaces or in lending money for the membership fee.

\section{Möckernkiez eG}

Another housing co-operative is the Mockernkiez Initiative in Berlin, registered as a cooperative in 2009. Its 1,500 members (in 2014) plan to build and inhabit a new neighbourhood in the inner city with ten to twelve apartment blocks, creating 460 flats and nineteen business units by 2017.

Members aim to relate ecofriendliness to business and argue that (socially) sustainable urban development can only be based on a more systematic use of ecologic building materials while making living conditions more sustainable. Some of the business units will be used for public children's and youth clubs open to all, a kindergarten, an accessible hotel and an organic supermarket. It explicitly targets the ecological dimension of sustainability by constructing passive houses with ecological building materials (including rooftop and wall greening), by raising awareness of natural resources and by introducing new technologies such as wastewater heat usage, block heating stations, photovoltaic rooftop systems and smart energy grids. In addition, the members share a vision of affordable housing that is intergenerational, barrier free, multicultural and socially inclusive.

\section{Participatory capacities}

During planning stages, bimonthly members' meetings with discussions on various topics took place that were each attended by more than 200 members. In addition, various groups worked on concepts and strategies (mobility, barrier-free structures, participation, ecology, 
the design of common and public areas etc.) in order to include individual ideas and needs sometimes with support of external experts. In addition, a concept for participation within the co-operative was developed by the managing board, describing the different forms and structures of co- operative participation that would be incorporated. Many members conceive the group explicitly to be not only a housing co-operative, but a network of civil society members shaping their neighbourhood, including various other associations and institutions. This is echoed in several statements that the co-operative as an organisation as well as its individual members should actively contribute to integrating people with less money and to reducing poverty, social neglect and unemployment locally. But they are also aware that their current makeup, with a majority of senior citizens, might constrain a diversification of their member structure. Despite the high levels of participation among members, the daily running of the co-operative business is still delegated to the executive and the supervisory board. Some conflicts emerged between members and the managing board because of differing ideas on how much time would be needed for implementation and on how much money would be spent on specific measures. ${ }^{35}$

Since, at time of writing, the co-operative has not yet started to build the neighbourhood, the extent to which its ambitious aims will be realised is unclear. The general public's reception of the project, however, can be described as positive. According to some members' statements the varied methods of communication have already triggered learning processes among members, the executive board and local politicians. This communication has also increased the quality of discussions and the members' dedication to the project.

\section{Solidary capacities}

Members of this housing co-operative defined solidarity as the production of collectively owned material and immaterial values that couldn't be created by individuals. A prominent topic in meetings and discussions is the relation of collective approaches to climate protection and to social inclusiveness, as several members emphasised the importance of barrier-free neighbourhoods and the integration of people with less money in co-operative structures and ecofriendly lifestyles, as well as a general need to reduce resource consumption. Examples given for collectively owned material values were joint investment in larger electrical devices (e.g. washing machines), sharing cars and providing services for both members and neighbours (such as children's daycare). In order for residents to relate to their neighbourhood, the co-operative has already opened a meeting space for both members and non-members, where monthly energy counselling services are offered and group meetings can take place. Appreciated intangible values are meeting friends and neighbours; working together; lending money in order that others might join the cooperative; a barrier-free culture of communication, respect and awareness; the ability to give and receive criticism; exchanging knowledge on various matters; and networking. Some members of the co-operatives whom the authors interviewed during a research project mentioned that the level of positive personal communication they experience could 
only be possible within a co-operative. Others remarked that they prefer not to have too personal contacts within the co-operative, and that a limiting factor to actual solidarity could be the growing number of members.

\section{Conclusions}

While the German co-operative movement is in many aspects different from those in other countries, these three short illustrations of housing co-operatives provide insight into today's co-operative housing landscape - and into challenges experienced while implementing participatory and solidary structures in the context of local climate protection. With a traditionally strong focus on economic activities, a growing number of small and larger German housing co-operatives already implement environmentally sustainable solutions. One major challenge for a transition towards a sustainable future though is the systematic connection of economic, social and environmental sustainability while dealing with diversity and complexity. In consequence, it is quite difficult to provide standardised recommendations for a co-operative transition towards sustainability.

Individual contributions to participation and solidarity within a cooperative are not necessarily a consequence of its size or age. But we can identify some crucial aspects that facilitate participatory and solidary structures for local climate protection. Raising awareness for issues of sustainability within a member-based organisation is clearly related to the objectives of the co-operative and to the interests of its members. In addition, providing different opportunities for communication and participation is crucial, as they allow for informal and formal exchange of opinions, knowledge, concerns and decisions. These opportunities may range from local meeting spaces to consultation processes and workshops about specific climate-related topics, and to establishing network structures with other, climate-aware organisations.

While it has to be stated that the institutionalised structure of a cooperative is not the only form of organisation to successfully implement local climate protection measures, linking cooperatives' values such as participation and solidarity to climate protection might be a major asset - especially if a co-operative as an entity engages in climate protection.

Nonetheless, in order to achieve results in climate protection, co-operatives need to network with politics, the economy and civilsociety groups. While many larger housing cooperatives (particularly in eastern Germany) are already working closely with municipalities, smaller co-operatives tend to not be perceived as potential partners for local climate protection at this time. In any case, personal contacts with politicians and excellent public relations are indispensable. But there are many small co-operatives with unpaid executive boards and limited resources who are struggling for their existence on a day-to-day basis, with not much time left for networking and lobbying. Nonetheless, with an already stronger emphasis on sustainability and climate protection, co-operatives have the potential to 
develop long-term solutions for their members' benefit, as well as to promote new, more sustainable behavioural and social patterns of action for individuals, civil society, policymakers and economic actors.

\section{Notes}

1 Intergovernmental Panel on Climate Change (IPCC), Climate Change 2014: Synthesis Report, Contribution of Working Groups I, II and III to the Fifth Assessment Report of the Intergovernmental Panel on Climate Change (Geneva: IPCC, 2014); see also IPCC, Fourth Assessment Report on Scientific Aspects of Climate Change for Researchers, Students, and Policymakers (Geneva: IPCC, 2007).

2 Climate protection in this context refers to actions taken to reduce greenhouse gas emissions, while adaptation to climate change refers to behavioural and structural adjustment to changing conditions of the environment.

3 Elinor Ostrom, 'Nested externalities and polycentric institutions: must we wait for global solutions to climate change before taking actions at other scales?', Economic Theory 49:2 (2012), 353-69.

4 N. W. Adger, Social Capital and Climate Change, Tyndall Centre Working Paper 8, Norwich: University of East Anglia, 2001), p. 1.

5 J. Ropke, 'Wirtschaftlicher Wandel und genossenschaftliches Unternehmertum' (Economic change and co-operative entrepreneurship) in Marburg Consult, ed., Genossenschaftliche Selbsthilfe und Struktureller Wandel (Marburg: Marburg Consult, 1992), pp. 13-33.

6 B. Flieger, Produktivgenossenschaft als fortschrittsfähige Organisation: Theorie, Fallstudie, Handlungshilfen (Productive associations as progressive proof organisations: theory, case study, practical aids) (Marburg: Metropolis Verlag, 1996), p. 33; International Cooperative Alliance (ICA), 'Statement of Co-operative Identity, Values and Principles' (1995), http://ica.coop/en/whats-co-op/co-operative-identity-values-principles (accessed 15 February 2016).

7 C. Sanchez Bajo and B. Roelants, Capital and the Debt Trap: Learning From Co-operatives in the Global Crisis (Basingstoke and New York: Palgrave Macmillan, 2011); T. Brockmeier and U. Fehl, eds, Volkswirtschaftliche Theorie der genossenschaftlichen Kooperation (Economic theory of co-operative cooperation) (Gottingen: Vandenhoeck und Ruprecht, 2007); and R. Greve, Globalisierung der Wirtschaft: Auswirkungen auf lokale Unternehmen (Globalisation of the economy: impact on local businesses), Munsteraner Diskussionspapiere zum Nonprofit-Sektor Munster Nr. 4 (discussion papers for the nonprofit sector No. 4) (2000), http://nbn-resolving.de/urn:nbn:de:0168-ssoar-373851, accessed 20 January 2016, p. 7

8 F. Braudel, Civilization and Capitalism, 3 vols, trans. S. Reynolds (New York: Harper \& Row, 1979).

9 M. Patera, 'Genossenschaftliche Forderbilanz' (Co-operative funding balance) in J. Laurinkari, ed., Genossenschaftswesen: Lehr- und Handbuch (Co-operative studies: teaching and manual) (Munich: Oldenbourg, 1990), pp. 285-301, p. 287. 
10 UN Habitat, Cities and Climate Change: Global Report on Human Settlements (London: UN Habitat, 2011).

11 V. Beuthien, T. Brockmeier and H. Klose, Materialien zum Genossenschaftsgesetz, Band V: Genossenschaftsrecht der SBZ und DDR 1945-1990 (Materials for Co-operatives Act, Volume V: co-operative law of SBZ and DDR 1945-1990) (Gottingen: Vandenhoeck \& Ruprecht, 1997).

12 Carolin Schröder and Heike Walk, Genossenschaften und Klimaschutz: Akteure für zukunftsfähige, solidarische Städte, Buchreihe 'Bürgergesellschaft und Demokratie' (Heidelberg: Springer, 2014).

13 C. von Blanckenburg, 'Genossenschaftliche Partizipationsstrukturen als Teil der besonderen Handlungsmoglichkeiten im Klimaschutz: Partizipation in Genossenschaften und im Nachhaltigkeitsdiskurs' (Co-operative participation structures as part of the special opportunities for action on climate change: participation in co-operatives and the sustainability discourse) in Schroder and Walk, Genossenschaften und Klimaschutz, pp. 257-83.

14 lbid.

15 Schröder and Walk, Genossenschaften und Klimaschutz.

16 W. Vogt, Genossenschaften - eine andere Form des Wirtschaftens: Ein Reader der Parlamentarischen Linken in der SPD-Bundestagsfraktion (Co-operatives -another form of economic activity: a reader of the Parliamentary Left in the SPD parliamentary group) (Berlin, 2011), p. $30 \mathrm{fn}$.

17 H. Bonus, Das Selbstverständnis moderner Genossenschaften: Rückbindung von Kreditgenossenschaften an ihre Mitglieder (The self-image of modern co-operatives: back donation of credit unions to their members) (Tubingen: C. B. Mohr, 1994), pp. 45-6; Vogt, Genossenschaften, p. 22.

18 S. Gherardi and A. Masiero, 'Solidarity as a networking skill and a trust relation: its implications for co-operative development, Economic and Industrial Democracy 11 (1990), 553-74, p. 554.

19 C. Schröder, 'Neue Formen stadtischer Solidaritat: Das Beispiel Genossenschaften' (New forms of urban solidarity: the example of co-operatives) in Schroder and Walk, Genossenschaften und Klimaschutz, pp. 73-91.

20 Vogt, Genossenschaften.

21 W. Hardtwig, "'Genossenschaft" in der deutschen Geschichte: Wirtschafts- und Lebensformen' ('Co-operative' in German history: forms of economy and ways of life) in H. J. Rosner and F. Schulz-Nieswandt, eds, Beiträge der genossenschaftlichen Selbsthilfe zur wirtschaftlichen und sozialen Entwicklung (Contributions of co-operative self-help to economic and social development), Teilband 1, Neue Kolner Genossenschaftswissenschaft Band 5 (Sub-band 1, New Cologne Co-operative Science vol. 5) (Berlin: LIT Verlag, 2009), pp. 27-48.

22 M. Stappel, Die deutschen Genossenschaften 2009: Entwicklungen - Meinungen - Zahlen (Sonderthema: Nach der Krise) (The German co-operatives 2009: developments opinions - numbers (special issue: after the crisis)) (Wiesbaden: DG-Verlag, 2009). 
23 D. Atmaca, 'Produktivgenossenschaften: Zwischen Utopie und Realismus' (Producer cooperatives: between utopia and realism) in T. Brockmeier and U. Fehl, eds, Volkswirtschaftliche Theorie der (genossenschaftlichen) Kooperation: Marburger Schriften zum Genossenschaftswesen (Economic theory of co-operation, Marburgers' writings on the co-operative system), Vol. 100 (Marburg: ifG Marburg, 2007), pp. 837-46.

24 DZ Bank Research, Konjunktur und Kapitalmarkt: Genossenschaften in Deutschland (Economic and capital markets: co-operatives in Germany) (Frankfurt am Main: DZ Bank Research, 2011).

25 S. Elsen, 'Genossenschaften als transformative Krafte auf dem Weg in die Postwachstumsgesellschaft' (Co-operatives as transformative forces on the way to the post-growth society) in Schroder and Walk, Genossenschaften und Klimaschutz, pp. 3447.

26 Those amendments made it easier to establish co-operatives, as the necessary number of founding members was reduced from seven to three and the compulsory auditing period for smaller co-operatives was extended from annual to biannual auditing.

27 F. Pollich, Die Auswirkungen der Genossenschaftsrechtsreform von 2006 auf die Neugründungen von Genossenschaften (The effects of the co-operative law reform of 2006 on the establishment of new co-operatives), Arbeitspapiere des Forschungsinstituts fur Genossenschaftswesen an der Universitat Erlangen-Nurnberg (Working Papers of the Research Institute of Co-operative Studies at the University of Erlangen-Nuremberg) 36 (Nuremberg: Universitat Erlangen-Nurnberg, 2009).

28 B. Flieger, Energiegenossenschaften: Eine klimaverantwortliche, burgernahe Energiewirtschaft ist moglich (Energy co-operatives: a climate responsible, communitybased energy economy is possible) in S. Elsen, ed., Ökosoziale Transformation: Solidarische Ökonomie und die Gestaltung des Gemeinwesens (Eco-social transformation: the solidarity economy and the design of the community) (Neu-Ulm: Ag Spak, 2011), pp. 315-38.

29 J. R. Muller and L. Holstenkamp, Zum Stand von Energiegenossenschaften in Deutschland: Aktualisierter Überblick über Zahlen und Entwicklungen zum 31.12.2014 (Luneburg: Leuphana Universitat Luneburg, 2015).

$30 \mathrm{H}$. Klemisch, 'Energiegenossenschaften als regionale Antwort auf den Klimawandel' (Energy co-operatives as a regional response to climate change) in Schroder and Walk, Genossenschaften und Klimaschutz, pp. 149-66, p. 150.

31 A. Zimmer, 'Genossenschaften als zivilgesellschaftliche Organisationen?' (Co-operatives as civil society organisations?), in H. J. Rosner and F. Schulz-Nieswandt, Beiträge der genossenschaftlichen Selbsthilfe zur wirtschaftlichen und sozialen Entwicklung (Contributions of co-operative self-help to economic and social development) (Berlin: LIT Verlag, 2009), pp. 143-56; H.-H. Munkner and G. Ringle, eds, Neue Genossenschaften und innovative Aktionsfelder: Grundlagen und Fallstudien (New co-operatives and innovative fields of action: principles and case studies) (Baden-Baden: Nomos Verlagsgesellschaft, 2010).

32 D. Atmaca, 'Genossenschaften in Zeiten raschen Wandels: Chancen einer nachhaltigen Organisationsform' (Co-operatives in times of rapid change: chances for a sustainable organisation) in Schroder and Walk, Genossenschaften und Klimaschutz, pp. 49-72. 
33 Sanchez Bajo and Roelants, Capital and the Debt Trap, p. 107.

34 Bundesministerium fur Verkehr, Bau und Stadtentwicklung (BMVBS), ed., Aktivierung von Potenzialen genossenschaftlichen Wohnens: Evaluierung der Empfehlungen der Expertenkommission Wohnungsgenossenschaften im Forschungsprogramm 'Experimenteller Wohnungs- und Stadtebau (ExWoSt)' (Activation of potential cooperative housing, an evaluation of the recommendations of the Commission of Experts on housing co-operatives in the research programme 'Experimental Housing and Urban Development (ExWoSt)'), BMVBS online publication No. 25 (Berlin: BMVBS, 2010), www.bbr.bund.de/BBSR/DE/Veroeffentlichungen/BMVBS/Online/2010/DL_ON252010.pd f?_blob=publicationFile \&v=2 (accessed 15 February 2016); BMVBW,

Wohnungsgenossenschaften: Potenziale und Perspektiven, Bericht der Expertenkommission Wohnungsgenossenschaften (Housing co-operatives: potential and prospects, report of the Expert Commission on Housing Co-operatives) (Berlin: BMVBW, 2004).

35 von Blanckenburg, 'Genossenschaftliche Partizipationsstrukturen', p. 161. 